\title{
Analisis Pengaruh CSR terhadap Manajemen Laba dengan Tata Kelola Perusahaan sebagai Variabel Moderasi
}

\author{
Meily Juliani \\ Universitas Internasional Batam \\ Meily.juliani@uib.ac.id \\ Cherry Ventty \\ Universitas Internasional Batam \\ 1842122.cherry@uib.edu
}

\begin{abstract}
The purpose of this research is to examine the social responsibility of earnings management with corporate governance as a moderating variable. Earnings management is measured by using discretionary accrual to check how much earnings management the company has done. Corporate social responsibility uses the GRI G4 index, while corporate governance uses several governance characteristics, namely board size, independent directors, ownership concentration, and institutional ownership to measure their role in regulating the relationship between social responsibility and earnings management. The research sample used 32 non-financial companies listed on the Indonesian Stock Exchange from 2016 to 2020. The research results show that corporate social responsibility has no significant positive impact on earnings management. The board size, institutional ownership, and block holder ownership have no significant impact on the relationship between social responsibility and earnings management. Independent directors as a mediator have a significant positive impact on the relationship between social responsibility and earnings management.

Keywords Earning Management (EM), Corporate Social Responsibility (CSR), Corporate Governance (CG)
\end{abstract}

\section{PENDAHULUAN}

Tanggung jawab sosial merupakan suatu kebijakan perusahaan melakukan operasional bisnis untuk mendapatkan hasil yang berdampak positif kepada masyarakat (Hopkins, 2014). Melalui inisiatif tanggung jawab sosial, perusahaan dapat memaksimalkan nilai bagi para pemangku kepentingan (Latif \& Sajjad, 2018). Tanggung jawab sosial merupakan salah satu cara di mana manajer dapat melakukan manipulasi informasi yang dibutuhkan oleh pemegang saham. Informasi laba termanipulasi ketika manajer mengandalkan pengetahuan dan pengontrolan atasan atas operasional dan laporan keuangan perusahaan menghitung laba tersebut untuk mencapai tujuan yang telah ditentukan.

Tanggung jawab sosial dapat menghasilkan laba untuk perusahaan, sehingga diperlukan suatu kebijakan yang mengatur tentang laba. Pada akuntansi, perusahaan memerlukan suatu kebijakan untuk mengatur laba pada laporan keuangan, kebijakan 
tersebut merupakan manajemen laba. Manajemen laba adalah kebijakan agar dapat mengarahkan pelaporan laba yang di laporkan pada laporan keuangan perusahaan (Honarvar \& Nakashima, 2014).

Tanggung jawab sosial merupakan hal yang di lakukan oleh perusahaan sebagai reputasi perusahaan yang mendatangkan keuntungan bagi perusahaan dalam sisi manapun. Tanggung jawab sosial dilakukan untuk memenuhi kontrak sosial, dimana ketika kontrak sosial terpenuhi maka akan menghasilkan laporan keuangan yang berkualitas (Kumala \& Siregar, 2020). Semakin tinggi aktivitas CSR perusahaan maka pemangku kepentingan akan semakin lebih menahan manajemen laba. Oleh karena itu tanggung jawab sosial mempengaruhi laba ataupun kualitas laporan keuangan yang ada, jika tidak dipergunakan dengan baik membuat para manajer melakukan tindakan manajemen laba.

Maka dari itu manajemen laba ialah suatu kebijakan yang diperlukan pengelola perusahaan dalam mengatur laba laporan keuangan. Dibutuhkan adanya pengelola perusahaan untuk mencegah adanya penyalahgunaan dalam tanggung jawab sosial perusahaan. Kusmayadi \& Badruzaman, (2018) menyimpulkan bahwa peran tata kelola perusahaan adalah untuk membantu pemangku kepentingan dalam mengawasi kinerja operasional perusahaan dan laporan keuangan perusahaan Kesempatan manajer dalam pengambilan keputusan CSR adalah salah satu masalah keagenan. Menurut penelitian Nasriatiti \& Ratnadi (2014), tata kelola perusahaan yang lemah dapat terjadi di karenakan tindakan manajer yang memberikan informasi yang tidak nyata terhadap laporan keuangan. Sistem tata Kelola perusahaan yang tidak efektif, maka para manajer menjadi lebih memiliki peluan untuk melakukan tindakan manajemen laba, sedangkan dengan sistem yang baik dapat mengurangi penyalahgunaan tanggung jawab sosial serta dapat meningkatkan kualitas laporan keuangan perusahaan (Latif \& Sajjad, 2020).

Masalah yang terjadi mengenai tindakan atas kurangnya pengawasan laporan keuangan seperti skandal yang terjadi pada perusahaan Enron pada tahun 2001, dimana skandal tersebut merupakan akibat dari tata kelola perusahaan yang buruk dalam mengatur manajemen laba. Kurangnya tata kelola dewan direksi perusahaan Enron dalam mengurus aktivitas perusahaan yang terkait dengan konfik kepentingan dan mengijinkan transaksi yang hanya dapat diakses oleh pihak dalam perusahaan. Enron merupakan perusahaan besar yang beroperasi di bidang energi, dimana perusahaan tersebut memanipulasi nominal pada laporan keuangan dengan menunda pencatatan piutang dikarenakan kas yang digunakan untuk kepentingan pribadi. Perusahaan melebih-lebihkan pendapatan sebesar US\$600 juta dan menutupi utang perusahaan sebesar US\$1,2 miliar (Nindita, 2012).

Kasus juga terjadi pada perusahaan di Indonesia seperti PT Garuda Indonesia pada tahun 2019 diduga melakukan penyalahgunaan dana tanggung jawab sosial yang diberikan oleh Bank Indonesia. Perusahaan diduga menyalahgunakan dana pada biaya internal perusahaan dimana dana tersebut seharusnya digunakan pada biaya eksternal perusahaan yang berhubungan dengan tanggung jawab sosial. Komisaris Garuda Indonesia mengatakan akan melakukan pemeriksaan kebenaran penggunaan dana tersebut, tetapi hingga berita tersebut diturunkan, pihak yang bersangkutan belum memberikan jawaban atas kasus dugaan tersebut (www.cnnindonesia.com).

Terdapat Badan Usaha Milik Negara lainnya yang melakukan tindakan manipulasi seperti perusahaan PT Perusahaan Listrik Negara meningkatkan laba pada 
tahun 2018 sebesar 162\% dari labanya dikarenakan melakukan penyesuaian piutang terdahulu dengan Perusahaan Gas Negara, dan menganggap piutang pemerintah sebagai pendapatan (www.cnnindonesia.com). Selain dari kasus Badan Usaha Milik Negara, terdapat perusahaan terbuka yang ada di indonesia, seperti pada perusahaan Tiga Pilar Sejahtera Food ditemukan terdapat akun persediaan, piutang, aset tetap, pendapatan, dan laba sebelum bunga, pajak, depresiasi, dan amortisasi pada laporan keuangan tahun 2017 yang mempunyai nominal besar. Perusahaan Wijaya Karya Beton membagikan dividen yang tidak sesuai kepada para pemegang saham dengan dividen yang lebih kecil dibandingkan dengan dividen yang sebenarnya (www.cnnindonesia.com).

Pada tahun 2020 Badan Pemeriksa Keuangan mengumumkan pernyataan dimana skandal mengenai perusahaan Jiwasraya yang melakukan pelanggaran standar akuntansi yang salah satunya terjadi pada tahun 2006 pada laporan keuangan yang sebenarnya mengalami kerugian namun dilaporkan oleh perusahaan mengalami keuntungan pada laporan keuangan tersebut. Pada tahun 2019 Jiwasraya melakukan pelanggaran prinsip investasi, dimana Jaksa Agung ST Burhanuddin berpendapat bahwa Jiwasraya menempatkan 95 dana invetasi pada aset beresiko. Kejaksaan Agung juga meminta Direktorat Jenderal Imigrasi Kementrian Hukum dan HAM mencekal 10 nama yang bertanggung jawab atas kasus Jiwasraya (www.cnnindonesia.com).

Peran tata kelola dapat mempengaruhi tanggung jawab sosial dan manajemen laba di mana dengan menyalahgunakan informasi dan data perusahaan. Maka dari itu dikarenakan banyaknya kasus yang terjadi di perusahaan Indonesia maka peneliti ingin mengetahui bagaimana pengaruh tanggung jawab sosial terhadap manajemen laba dengan moderasi tata kelola .

\section{LANDASAN TEORI}

A. Tanggung Jawab Sosial

Teori institusional adalah teori mengenai relasi tanggung jawab sosial dan manajemen laba, di mana menyatakan bahwa tanggung jawab sosial merupakan salah satu dari faktor organisasi, di mana mempunyai kemungkinan tidak memiliki hubungan signifikan terhadap manajemen laba. Tanggung jawab sosial di temukan signifikan positif terhadap manajemen laba dengan perusahaan yang melakukan aktivitas CSR untuk memenuhi harapan pemangku kepentingan akan lebih cenderung menahan manajemen laba. Namun pada penelitian Setiawan et al. (2019) menyimpulkan adanya pengaruh signifikan positif antara tanggung jawab sosial terhadap manajemen laba dan penelitian López-González et al. (2019) dan Habbash \& Haddad (2019) menjelaskan bahwa tanggung jawab sosial pengaruh positif terhadap manajemen laba.

Pada teori legitimasi berpendapat bahwa dengan mendorong manajemen melakukan CSR untuk memenuhi kontrak sosial maka laporan keuangan perusahaan akan lebih berkualitas. Tanggung jawab sosial di temukan signifikan negatif terhadap manajemen laba dengan perusahaan yang tidak melakukan aktivitas CSR dan tidak memenuhi harapan pemangku kepentingan akan lebih cenderung melakukan tindakan praktik manajemen laba (Kumala dan Siregar, 2020). Tanggung jawab sosial di temukan signifikan negatif terhadap manajemen laba (Choi et al. 2013).

\section{$H_{1}$ : Tanggung jawab sosial berpengaruh signifikan positif terhadap manajemen laba.}




\section{B. Ukuran Dewan}

Semakin besar jumlah anggota dewan semakin efektif dalam pengawasan dan pengendalian terhadap para manajer. Ukuran dewan merupakan peran penting di mana dapat mengurangi ataupun memantau konflik keagenan. Jumlah anggota dewan yang semakin besar akan lebih beragam dalam kemampuan, keterampilan, latar belakang akademis yang akan lebih membantu mencegah adanya masalah perusahaan, sehingga akan lebih menekankan tindakan manajemen laba (Sha, 2017). Buertey, et al. (2019) membuktikan bahwa ukuran dewan berpengaruh tidak signifikan terhadap manajemen laba dan tanggung jawab sosial. Choi, et al. (2013), Ntim dan Soobaroyen, (2013), Pekovic dan Vogt, (2020) membuktikan bahwa ukuran dewan berpengaruh signifikan positif terhadap manajemen laba dan tanggung jawab sosial.

\section{H2: Ukuran dewan sebagai moderasi berpengaruh signifikan positif dalam mempengaruhi tanggung jawab sosial dan manajemen laba.}

\section{Direktur Independen}

Direktur independen merupakan peran yang penting dalam melindungi kesejahteraan investor. Direktur independen pada dewan perusahaan dapat membatasi manajemen laba. Direktur independen yang efektif memberikan pengaruh yang signifikan terhadap pilihan manajemen. Direktur independen diharapkan dapat memperkuat fungsi dan tugas direksi, direktur independen berfungsi untuk mengawasi apakah para direksi telah memenuhi perannya dan tanggung jawabnya dengan baik (Supriatna \& Ermond, 2019). Pada penelitian Ntim \& Soobaroyen, (2013), Pekovic \& Vogt, (2020), Zaid, et al. (2020) membuktikan bahwa direktur independen berpengaruh signifikan positif terhadap hubungan tanggung jawab sosial. Sedangkan pada peneitian Sial, et al. (2019) berpendapat bahwa direktur independen berpengaruh signifikan negatif terhadap manajemen laba dan tanggung jawab sosial. Buertey, et al. (2019) membuktikan tidak adanya pengaruh direktur independen terhadap manajemen laba dan tanggung jawab sosial.

\section{H3: Direktur independen sebagai moderasi berpengaruh signifikan positif dalam mempengaruhi tanggung jawab sosial dan manajemen laba.}

\section{Kepemilikan Institusional}

Kepemilikan institusional memiliki tanggung jawab untuk menjaga kepentingannya dengan memastikan bahwa kepentingan pribadi manajer tidak melebihi kepentingan pemegang saham. Kepemilikan institusional mempunyai resiko yang lebih tinggi dibandingkan dengan pemegang saham individu dikarenakan kepemilikan institusional mempunyai saham yang lebih besar sehingga akan mengawasi manajer. Kepemilikan institusional merupakan salah satu peran yang dapat mengurangi aktivitas manajemen laba. Peran tersebut dapat mengatasi manajemen untuk memanfaatkan pelaporan laba yang tidak tepat dalam laporan keuangan, sehingga memberikan kualitas laba yang lebih tinggi. Namun menurut Amalia dan Didik, (2017) kepemilikan institusional hanya berperan sebagai pemilik perusahaan bersifat sementara, dimana peran ini hanya berfokus pada laba jangka pendek sehingga kurang efektifnya dalam mengawasi manajer dalam mengatasi penyalahgunaan tanggung jawab sosial maupun tindakan manajemen laba.

Ardiani dan Sudana, (2018), Choi, et al. (2013), Nariastiti dan Ratnadi, (2014), Ntim dan Soobaroyen, (2013), Sembiring, (2017) menemukan kepemilikan institusional berpengaruh signifikan negatif terhadap manajemen laba dan tanggung jawab sosial. 
Kepemilikan institusional di temukan pengaruh tidak signifikan terhadap manajemen laba dan tanggung jawab sosial (Buertey, et al. 2019).

H4: Kepemilikan institusional sebagai moderasi berpengaruh signifikan negatif dalam mempengaruhi tanggung jawab sosial dan manajemen laba.

\section{E. Konsentrasi Kepemilikan}

Konsentrasi kepemilikan dapat meningkatkan kualitas pemantauan manajerial. Konsentrasi kepemilikan dapat mengurangi masalah keagenan dan membatasi kepemilikan manajerial. Konsentrasi kepemilikan ini perlu diposisikan dengan efektif agar dapat mengurangi penyalahgunaan CSR. Penelitian Ntim \& Soobaroyen, (2013) konsentrasi kepemilikan berpengaruh positif terhadap tanggung jawab sosial dan indeks tata kelola perusahaan.

Konsentrasi kepemilikan di temukan memberikan dampak negatif pada tanggung jawab sosial (Choi, et al. 2013; Pekovic \& Vogt, 2020). Konsentrasi kepemilikan Konsentrasi kepemilikan di temukan pengaruh positif terhadap manajemen laba dan tanggung jawab sosial (Buertey, et al. 2019).

\section{H5: Konsentrasi kepemilikan sebagai moderasi berpengaruh signifikan positif dalam mempengaruhi tanggung jawab sosial dan manajemen laba.}

\section{METODOLOGI PENELITIAN}

Penelitian ini menguji data variabel yang berbentuk data numerik, maka penelitian data tersebut bersifat data kuantitatif. Penelitian tersebut merupakan penelitian di mana dapat di kategorikan sebagai penelitian dasar yang di gunakan dengan tujuan mengembangkan teori atas variabel penelitian tersebut.

Rancangan penelitian di kategorikan menjadi penelitian kasual komparatif di mana melakukan pengujian terhadap hubungan antar variabel yang bersangkutan dengan variabel independen tanggung jawab sosial dan ukuran dewan, direktur independen, kepemilikan institusional, konsentrasi kepemilikan menjadi variabel moderasi, serta manajemen laba sebagai variabel dependen (Buertey et al. 2019). Objek penelitian dengan perusahaan terdaftar BEI selama tahun 5 tahun yakni, tahun 2016 - 2020 sebagai objek penelitian. Berikut disimpulkan beberapa kriteria dalam pengambilan pemilihan sampel terhadap penelitian, yakni:

1. Laporan tahunan dan laporan keberlanjutan perusahaan non-finansial yang telah di audit dari tahun 2016 - 2020.

2. Laporan tahunan yang di laporkan berdasarkan tahun buku pada akhir tahun periode tersebut

\section{Variabel Dependen}

Pada penelitian tersebut manajemen laba digunakan sebagai variabel dependen. Manajemen laba diukur dengan menggunakan akrual diskresioner model cross sectional. Berikut adalah rumus yang diterapkan akrual dikresioner (Buertey et al., 2019).

$$
\begin{gathered}
T A C=N I-O C F \\
\frac{T A C}{A t-1}=\beta_{1}\left(\frac{1}{A t-1}\right)+\beta_{2}\left(\frac{\Delta R E V}{A t-1}-\frac{\Delta R E C}{A t-1}\right)+\beta_{3}\left(\frac{P P E}{A t-1}\right)
\end{gathered}
$$




$$
D A=\left(\frac{T A}{A t-1}\right)-N D A
$$

Dimana:

DA = Discretionary Accrual perusahaan

TAC $=$ Total akrual perusahaan

$\mathrm{NI}=$ Laba bersih perusahaan

$\mathrm{OCF}=$ Arus kas operasional perusahaan

$\mathrm{TA}=$ Total asset perusahaan

$\triangle \mathrm{REV}=$ Perubahan pada pendapatan perusahaan

$\triangle \mathrm{REC}=$ Perubahan pada piutang perusahaan

$\mathrm{PPE}=$ Aset tetap perusahaan

$\mathrm{NDAC}=$ Non-discretionary accrual perusahaan

\section{Variabel Independen}

Variabel independen yang digunakan pada penelitian ini adalah tanggung jawab sosial perusahaan. Menurut Ardiani dan Sudana, (2018) mengukur tanggung jawab sosial perusahaan dapat menggunakan GRI G4 dalam menganalisisnya. Perusahaan yang mengungkapkan kriteria GRI G4 tanggung jawab sosial perusahaan maka diberikan angka 1 , sedangkan yang tidak mengungkapkan diberikan angka 0 . Berikut adalah rumus pada penelitian ini:

$$
\text { CSRDI }=\frac{\text { Total item indeks di ungkapkan perusahaan }}{\text { Total item GRI G4 }}
$$

\section{Variabel Moderasi}

Variabel moderasi yang digunakan penelitian adalah dengan tata kelola perusahaan, yaitu ukuran dewan, direktur independen, kepemilikkan institusional, dan konsentrasi kepemilikkan.

1. Ukuran dewan adalah ukuran dewan direksi pada perusahaan tersebut. Dengan menggunakan jumlah seluruh direktur dewan pada perusahaan (Buertey et al. 2019, Pekovic dan Vogt, 2020).

$$
\text { Ukuran Dewan }=\text { Jumlah Dewan Direktur }
$$

2. Direktur independen adalah salah satu anggota dewan perusahaan yang mengawasi dewan direksi apakah telah menjalankan perannya dalam menjalankan tugas perusahaan. Direktur independen juga berperan memberikan masukan kepada dewan direksi. Direktur independen ini diukur dengan menggunakan persentase direktur noneksekutif independen dewan perusahaan (Buertey et al. 2019, Pekovic dan Vogt, 2020). Berikut adalah rumus pada penelitian ini:

$$
\text { Direktur Independen }=\frac{\text { Jumlah Direktur Independen }}{\text { Jumlah Dewan Direktur }}
$$

3. Kepemilikan Institusional merupakan saham yang dimiliki perusahaan keuangan seperti perusahaan dana pensiun, asuransi, bank dan perusahaan keuangan lainnya. Investor institusional dapat mempengaruhi keputusan perusahaan melewati hak suara yang ada pada perusahaan tersebut (Choi et al. 2013). Variabel tersebut diukur dengan menggunakan tingkat persentase saham yang dimiliki oleh perusahaan keuangan (Ardiani dan Sudana, 2018, Buertey et al. 2019). Berikut adalah rumus pada penelitian ini: 


$$
\text { Kepemilikan Institusional }=\frac{\text { Jumlah Kepemilikan Institusional }}{\text { Jumlah Saham Beredar }}
$$

4. Konsentrasi kepemilikan adalah pemegang saham yang setidaknya memiliki 5\% saham perusahaan. Konsentrasi kepemilikkan diukur dengan tingkat persentase saham yang dimiliki oleh investor dengan setidaknya 5\% dari kepemilikan ekuitas di perusahaan (Buertey et al. 2019, Choi et al. 2013, Ntim dan Soobaroyen, 2013).

$$
\text { Konsentrasi Kepemilikan }=\frac{\text { Jumlah saham investor } 5 \%}{\text { Jumlah saham beredar }}
$$

\section{Variabel Kontrol}

Variabel kontrol yang digunakan pada penelitian ini adalah profitabilitas, leverage, ukuran perusahaan, sumber keuangan perusahaan, pertumbuhan, dan jenis perusahaan audit.

1. Profitabilitas, menurut penelitian Anwar \& Buvanendra, (2016), Buertey, et al. (2019), Kao, et al. (2019) profitabilitas diukur dari pengembalian aset di mana diukur dari aset yang ada pada perusahaan.

$$
\text { Pengembalian Aset }=\frac{\text { Laba bersih setelah pajak }}{\text { Total Aset }}
$$

2. Leverage, pemimjaman dana untuk mendapatkan imbalan dari suatu investasi. Leverage diukur dengan rasio utang terhadap aset (Anwar dan Buvanendra, 2016, Buertey et al. 2019, Kao et al. 2019).

$$
\text { Rasio Hutang Aset }=\frac{\text { Jumlah Hutang }}{\text { Jumlah Aset }}
$$

3. Ukuran perusahaan, aktiva yang dimiliki oleh perusahaan. Ukuran perusahaan diukur dengan jumlah aset pada skala log (Anwar dan Buvanendra, 2016, Buertey et al. 2019).

$$
\text { Ukuran Perusahaan = Logaritma Total Aset }
$$

4. Sumber keuangan perusahaan, dana pada perusahaan didapatkan. Berdasarkan penelitian pada Buertey, et al. (2019) sumber keuangan perusahaan diukur dengan menggunakan arus kas aktivitas operasi terhadap total aset.

$$
\text { Pengembalian Tunai atas Aset }=\frac{\text { Arus Kas Aktivitas Operasi }}{\text { Total Aset }}
$$

5. Pertumbuhan perusahaan, kemampuan perusahaan dalam meningkatkan skala usaha. Pada penelitian Anwar \& Buvanendra, (2016), Buertey, et al. (2019), Kao, et al. (2019) pertumbuhan perusahaan diukur dengan menggunakan persentase perubahan pendapatan.

$$
\text { Pertumbuhan }=\frac{\text { Penjualan }(\mathrm{t})-\text { Penjualan }(t-1)}{\text { Penjualan }(t-1)}
$$

6. Jenis perusahaan audit, perusahaan audit yang besar dapat melindungi kepentingan para pemangku kepentingan melalui kualitas pekerjaan sebagai auditor. Penelitian pada Buertey, et al. (2019) berpendapat jenis perusahaan audit diukur dengan dummy variabel, jika perusahaan menggunakan perusahaan audit big4 diberikan angka 1, dan jika perusahaan audit bukan big4 maka diberikan angka 0 . 
Data penelitian tersebut merupakan data sekunder, di mana data yang telah di publikasikan di situs web Bursa Efek Indonesia maupun situs web perusahaan masingmasing. Penelitian tersebut peneliti menggunakan metode analisis data regresi panel, di mana mengamati relasi variabel independen dengan variabel dependen di mana disertai variabel moderasi atas hubungan tersebut. Data yang dianalisis terdiri dari statistik deskriptif dan uji hipotesis. Setelah melakukan analisis statistika deskriptif, selanjutnya melakukan uji pengukuran model struktural yaitu, koefisien determinasi dan koefisien jalur pada penelitian ini menggunakan aplikasi Smart PLS (Smart Partial Least Square) 3.0 untuk menguji regresi data yang telah dikumpulkan dan pada statistika deskriptif menggunakan aplikasi Statistical Product and Service Solution (SPSS).

\section{HASIL PENELITIAN}

Tabel 1 Analisis Deskriptif Variabel Penelitian

\begin{tabular}{|l|l|l|l|l|l|}
\hline Variabel & \multicolumn{1}{|c|}{$\mathbf{N}$} & Rata-Rata & Minimum & Maksimum & \multicolumn{1}{|c|}{$\begin{array}{c}\text { Standar } \\
\text { Deviasi }\end{array}$} \\
\hline DACC & 160.0000 & -0.6890 & -5.8599 & 0.6216 & 0.6975 \\
\hline CSR & 160.0000 & 0.2677 & 0.0879 & 0.6374 & 0.1139 \\
\hline BO & 160.0000 & 0.6202 & 0.0000 & 0.9831 & 0.1903 \\
\hline BI & 160.0000 & 0.0822 & 0.0000 & 0.3333 & 0.1033 \\
\hline BS & 160.0000 & 6.1313 & 3.0000 & 11.0000 & 1.8535 \\
\hline IO & 160.0000 & 0.4779 & 0.0000 & 0.9831 & 0.3057 \\
\hline FFS & 160.0000 & 0.0796 & -0.2210 & 0.4198 & 0.0937 \\
\hline $\begin{array}{l}\text { FS (Miliar } \\
\text { Rupiah) }\end{array}$ & 160.0000 & 44413.4584 & 883.288615 & 351958.0000 & 58712.04483 \\
\hline Growth & 160.0000 & 0.0144 & -2.3767 & 0.9948 & 0.3260 \\
\hline LEV & 160.0000 & 0.5607 & 0.1264 & 6.4005 & 0.5202 \\
\hline ROA & 160.0000 & 0.0506 & -0.4509 & 0.4666 & 0.0897 \\
\hline
\end{tabular}

Sumber: Hasil olah data, 2021

Tabel 2 Analisis Frekuensi Variabel Penelitian

\begin{tabular}{|c|c|c|c|c|c|c|}
\hline \multirow{2}{*}{ Variabel } & \multicolumn{2}{|c|}{ Dummy: 0 } & \multicolumn{2}{c|}{ Dummy: 1 } & \multicolumn{2}{c|}{ Total } \\
\cline { 2 - 7 } & $\mathbf{N}$ & $\mathbf{\%}$ & $\mathbf{N}$ & $\mathbf{\%}$ & $\mathbf{N}$ & \% \\
\hline Jenis Perusahaan Audit & 10 & 23.7500 & 38.0000 & 73.3333 & 45 & 100.0000 \\
\hline
\end{tabular}

Sumber: Hasil olah data, 2021

Pada Tabel di atas manajemen laba menunjukkan data dengan rata rata -0.6890 , nilai terkecil sebesar -5.8599 , nilai tertinggi sebesar 0.6216, dan simpangan baku sebesar 0.6975 . Tanggung jawab sosial menunjukkan data dengan rata rata 0.2677 , nilai terkecil sebesar 0.0879, nilai terbesar sebesar 0.6374, dan simpangan baku sebesar 0.1139. Konsentrasi kepemilikan menunjukkan data dengan rata rata 0.6202 , nilai terkecil 0.0000 , nilai terbesar sebesar 0.9831, dan simpangan baku sebesar 0.1903. Direktur independen menunjukkan data dengan rata rata 0.0822 , nilai terkecil sebesar 0.0000 , nilai terbesar sebesar 0.3333, dan simpangan baku sebesar 0.1033. Ukuran dewan menunjukkan data dengan rata rata 6.1313, nilai terkecil sebesar 3, nilai terbesar sebesar 11 anggota dewan direksi, dan simpangan baku sebesar 1.8535. Kepemilikan institusional menunjukkan 
data dengan rata rata 0.4799 , nilai terkecil sebesar 0.0000 , nilai terbesar sebesar 0.9831 , dan simpangan baku sebesar 0.3057 .

Sumber keuangan perusahaan menunjukkan data dengan nilai rata 0.0796, nilai terkecil sebesar -0.2210, nilai terbesar 04198, dan simpangan baku sebesar 0.0937. Ukuran Perusahaan menunjukkan data dengan nilai rata rata 44.413,4584 miliar rupiah, nilai terkecil sebesar 883,2886 miliar rupiah, nilai terbesar sebesar 351.958 miliar rupiah, dan simpangan baku sebesar 58.712,0488 miliar rupiah. Pertumbuhan menunjukkan data dengan rata rata 0.0144 , nilai terkecil sebesar -2.3767 , nilai terbesar sebesar 0.9948 , dan simpangan baku sebesar 0.3260. Hutang menunjukkan data dengan rata rata 0.5607 , nilai terkecil sebesar 0.1264, nilai terbesar sebesar 6.4005, dan simpangan baku sebesar 0.5202. Profitabilitas menunjukkan data dengan rata rata 0.0506 , nilai terkecil sebesar 0.4509 , nilai terbesar sebesar 0.4666, dan simpangan baku sebesar 0.0897. Jenis perusahaan audit dalam data penelitian tersebut dapat di simpulkan bahwa sebanyak $76.2500 \%$ menggunakan empat (4) besar firma audit dibandingkan dengan firma audit yang tidak dalam empat (4) besar adalah $23.7500 \%$.

Tabel 3 Uji Koefisien Determinasi

\begin{tabular}{|l|l|}
\hline \multicolumn{1}{|c|}{ Variabel } & Adjusted $R$ Square \\
\hline Manajemen Laba & 0.3241 \\
\hline
\end{tabular}

Sumber: Hasil olah data, 2021

Pada Tabel diatas manajemen laba sebesar 0.3241, di mana dapat dijelaskan bahwa variabel manajemen laba yang dapat dijelaskan oleh variabel yang terdapat dalam model penelitian bahwa model sangat lemah dan tidak baik dalam dependen diperjelaskan oleh variabel tersebut. Sedangkan sisanya 0.6759 dijelaskan oleh variabel lainnya yang tidak terdapat dalam penelitian tersebut.

Tabel 4 Uji Relevan Prediksi

\begin{tabular}{|l|l|l|l|}
\hline \multicolumn{1}{|c|}{ Variabel } & SSO & SSE & $Q^{2}(=1-S S E / S S O)$ \\
\hline DACC & 160.0000 & 114.8460 & 0.2822 \\
\hline CSR & 160.0000 & 160.0000 & \\
\hline BO & 160.0000 & 160.0000 & \\
\hline BI & 160.0000 & 160.0000 & \\
\hline BS & 160.0000 & 160.0000 & \\
\hline IO & 160.0000 & 160.0000 & \\
\hline CSR -> BS -> DACC & 160.0000 & 160.0000 & \\
\hline CSR -> BI -> DACC & 160.0000 & 160.0000 & \\
\hline CSR -> IO -> DACC & 160.0000 & 160.0000 & \\
\hline CSR -> BO -> DACC & 160.0000 & 160.0000 & \\
\hline FFS & 160.0000 & 160.0000 & \\
\hline FS & 160.0000 & 160.0000 & \\
\hline Growth & 160.0000 & 160.0000 & \\
\hline Lev & 160.0000 & 160.0000 & \\
\hline ROA & 160.0000 & 160.0000 & \\
\hline BIG4 & 160.0000 & 160.0000 & \\
\hline
\end{tabular}

Sumber: Hasil olah data, 2021 
Nilai dari relevan prediksi sebesar 0.2822 dapat dikatakan model tersebut cocok dengan data tersebut, tetapi jika mendekati angka 1 semakin baik.

Tabel 5 Uji Goodness of Fit

\begin{tabular}{|l|l|l|}
\hline \multicolumn{1}{|c|}{ Variabel } & Communality & Average Communality \\
\hline DACC & 160.0000 & 1.0000 \\
\hline CSR & 160.0000 & 1.0000 \\
\hline BO & 160.0000 & 1.0000 \\
\hline BI & 160.0000 & 1.0000 \\
\hline BS & 160.0000 & 1.0000 \\
\hline IO & 160.0000 & 1.0000 \\
\hline CSR -> BS -> DACC & 160.0000 & 1.0000 \\
\hline CSR -> BI -> DACC & 160.0000 & 1.0000 \\
\hline CSR -> IO -> DACC & 160.0000 & 1.0000 \\
\hline CSR -> BO -> DACC & 160.0000 & 1.0000 \\
\hline FFS & 160.0000 & 1.0000 \\
\hline FS & 160.0000 & 1.0000 \\
\hline Growth & 160.0000 & 1.0000 \\
\hline Lev & 160.0000 & 1.0000 \\
\hline ROA & 160.0000 & 1.0000 \\
\hline BIG4 & 160.0000 & 1.0000 \\
\hline
\end{tabular}

Sumber: Hasil olah data, 2021

$\mathrm{GoF}=\sqrt{\overline{\operatorname{Com}} \times \overline{R^{2}}}$

$\mathrm{GoF}=\sqrt{1 \times 0.3241}$

$\mathrm{GoF}=0.5692$

Nilai dari Gof sebesar 0.5692, hasil dari penelitian menurut Gof termasuk dalam kategori besar karena melewati 0.38. Nilai tersebut dapat di simpulkan bahwa kemampuan model penelitian valid.

Tabel 6 Uji Koefisien Jalur

\begin{tabular}{|l|l|l|l|l|l|}
\hline \multicolumn{1}{|c|}{ Variabel } & \multicolumn{1}{|c|}{$\begin{array}{c}\text { Original } \\
\text { Sample }\end{array}$} & $\begin{array}{c}\text { Sample } \\
\text { Mean }\end{array}$ & $\begin{array}{c}\text { Standard } \\
\text { Deviation }\end{array}$ & $\begin{array}{c}\text { T } \\
\text { Statistics }\end{array}$ & $\begin{array}{c}\text { P } \\
\text { Values }\end{array}$ \\
\hline CSR -> DACC & -0.0018 & 0.0073 & 0.0703 & 0.0262 & 0.9791 \\
\hline BO -> DACC & 0.0184 & 0.019 & 0.0556 & 0.3307 & 0.741 \\
\hline BI -> DACC & -0.1087 & -0.0994 & 0.0996 & 1.0912 & 0.2757 \\
\hline BS -> DACC & 0.0984 & 0.1057 & 0.0676 & 1.4549 & 0.1463 \\
\hline IO -> DACC & -0.0557 & -0.0514 & 0.084 & 0.6629 & 0.5077 \\
\hline $\begin{array}{l}\text { CSR -> BS -> } \\
\text { DACC }\end{array}$ & 0.1359 & 0.1519 & 0.0747 & 1.8191 & 0.0695 \\
\hline $\begin{array}{l}\text { CSR -> BI -> } \\
\text { DACC }\end{array}$ & -0.1438 & -0.1421 & 0.0728 & 1.9757 & 0.0487 \\
\hline
\end{tabular}




\begin{tabular}{|l|l|l|l|l|l|}
\hline $\begin{array}{l}\text { CSR -> IO -> } \\
\text { DACC }\end{array}$ & 0.0313 & 0.0321 & 0.0601 & 0.521 & 0.6026 \\
\hline $\begin{array}{l}\text { CSR -> BO -> } \\
\text { DACC }\end{array}$ & 0.0039 & 0.0162 & 0.0667 & 0.0588 & 0.9531 \\
\hline FFS -> DACC & -0.4579 & -0.4847 & 0.1711 & 2.6765 & 0.0077 \\
\hline FS -> DACC & 0.1528 & 0.1544 & 0.0764 & 1.9987 & 0.0462 \\
\hline Growth -> DACC & -0.256 & -0.2537 & 0.1256 & 2.0383 & 0.042 \\
\hline Lev -> DACC & 0.1944 & 0.2017 & 0.0752 & 2.5858 & 0.01 \\
\hline ROA -> DACC & 0.5009 & 0.5171 & 0.1376 & 3.6394 & 0.0003 \\
\hline BIG4 -> DACC & -0.284 & -0.2817 & 0.0662 & 4.289 & 0 \\
\hline
\end{tabular}

Pada data table diatas dapat di simpulkan bahwa tanggung jawab sosial berdampak positif dan tidak signifikan pada variabel dependen. Hasil penelitian ini menunjukkan setiap peningkatan CSR meningkatnya manajemen laba, dan mengelola labanya dengan melibatkan aktivitas CSR untuk menutupi kesalahan dari perusahaan kepada pihak investor (Buertey et al. 2019, Jordaan et al. 2018, Putriana et al. 2018).

Konsentrasi kepemilikan berdampak positif dan tidak signifikan pada variabel dependen, dimana pada penelitian Amalia and Didik, (2017) menjelaskan peranan tata kelola direksi dan para manajemen sebagai pelaksana mempunyai peluang untuk melakukan tindakan manajemen laba. Direktur independen berdampak positif dan tidak signifikan pada variabel dependen, banyaknya perusahaan yang tidak menggunakan direktur independen sehingga perusahaan cenderung melakukan manajemen laba (Almalita, 2018). Ukuran dewan berdampak positif dan tidak signifikan pada variabel dependen, berdasarkan penelitian pada Almalita, (2018) bahwa hasil tersebut dapat disimpulkan tidak mempunyai kemampuan dalam mempengaruhi keputusan perusahaan. Kepemilikan institusional berdampak positif dan tidak signifikan pada variabel dependen, dimana dengan memiliki saham kepemilikkan saham institusional lebih mempunyai kemampuan kontrol, tetapi pada hasil penelitian menunjukkan bahwa kepemilikkan saham tidak dapat mengurangi tindakan manajemen laba (Amalia dan Didik, 2017).

Konstruk moderasi ukuran dewan terhadap hubungan tanggung jawab sosial dan manajemen laba berdampak positif dan tidak signifikan, hasil ini menunjukkan ukuran dewan kurang mampu dalam menahan manajemen laba dengan direktur yang lebih banyak lebih melibatkan tanggung jawab sosial pada perusahaan. Perusahaan dengan direktur yang lebih sedikit maka perusahaan tersebut tidak melibatkan CSR (Buertey et al. 2019). Konstruk moderasi direktur independen terhadap hubungan tanggung jawab sosial dan manajemen laba berdampak positif dan signifikan, berdasarkan penelitian Ntim \& Soobaroyen, (2013), Pekovic \& Vogt, (2020), Zaid, et al. (2020) dapat disimpulkan bahwa perusahaan jika memiliki direktur independen yang lebih besar maka akan semakin besar kemungkinan dalam menahan penggunaan CSR yang merugikan sebagai bentuk reputasi jaminan untuk terlibat dalam manajemen laba.

Konstruk moderasi kepemilikan institusional terhadap hubungan tanggung jawab sosial dan manajemen laba berdampak positif dan tidak signifikan, hasil tersebut dapat disimpulkan bahwa perusahaan jika memiliki kepemilikian insitutional yang lebih besar dari saham perusahaan maka akan lebih cenderung mengurangi hubungan antara CSR dan manajemen laba (Buertey et al. 2019). Konstruk moderasi konsentrasi kepemilikan terhadap hubungan tanggung jawab sosial dan manajemen laba berdampak positif dan tidak signifikan, berdasarkan penelitian pada Buertey, et al. (2019) dapat disimpulkan 
hasil penelitian menunjukkan konsentrasi kepemilikkan mempunyai insentif yang lebih tinggi dapat memantau dan mengurangi kesempatan manajerial untuk memperoleh kepentingannya dengan melebihi biaya. Konsentrasi kepemilikan meningkat bertujuan untuk mencegah penggunaan CSR yang merugikan.

Sumber keuangan perusahaan berdampak positif dan signifikan pada variabel dependen, hasil tersebut dapat disimpulkan bahwa semakin tinggi sumber keuangan perusahaan maka akan dapat mengatasi peluang atas tindakan manajemen laba (Hastuti, 2019). Ukuran perusahaan berdampak positif dan signifikan pada variabel dependen, hasil tersebut dapat disimpulkan dari penelitian Medyawati and Dayanti, (2016) bahwa perusahaan dapat mempengaruhi pengelolaan laba, dengan semakin besarnya ukuran perusahaan, maka semakin tingginya pengelolan laba. Pertumbuhan berdampak positif dan signifikan pada variabel dependen, dimana pertumbuhan perusahaan dapat memberikan dampak terhadap tindakan manajemen laba, dimana dengan pertumbuhan yang rendah maupun tinggi, perusahaan akan mempunyai peluang dalam melakukan tindakan manajemen laba (Dwiarti dan Hasibuan, 2018).

Leverage berdampak positif dan signifikan pada variabel dependen, berdasarkan penelitian pada Febria, (2020) dapat disimpulkan bahwa perusahaan tidak melalui hutang dalam melakukan tindakan manajemen laba. Profitabilitas berdampak positif dan signifikan pada variabel dependen, berdasarkan penelitian pada Almalita, (2018) perusahaan menggunakan informasi profitabilitas secara benar, sehingga dapat menghindari tindakan manajemen laba. Jenis perusahaan audit berdampak positif dan signifikan pada variabel dependen, berdasarkan penelitian pada Almalita, (2018) dapat disimpulkan bahwa perusahaan audit mampu dalam mendeteksi proses audit atas tindakan manajemen laba yang dilakukan oleh perusahaan klien.

\section{KESIMPULAN}

Penelitian terhadap tanggung jawab sosial terhadap manajemen laba dengan tata kelola perusahaan sebagai moderasi, berdasarkan analisis dari pengujian tersebut, dapat disimpulkan:

1. Tanggung jawab sosial berpengaruh tidak signifikan terhadap manajemen laba.

2. Ukuran dewan sebagai moderasi berpengaruh tidak signifikan dalam mempengaruhi tanggung jawab sosial dan manajemen laba.

3. Direktur independen sebagai moderasi berpengaruh signifikan positif dalam mempengaruhi tanggung jawab sosial dan manajemen laba.

4. Kepemilikan institusional sebagai moderasi berpengaruh tidak signifikan dalam mempengaruhi tanggung jawab sosial dan manajemen laba.

5. Konsentrasi kepemilikan sebagai moderasi berpengaruh tidak signifikan dalam mempengaruhi tanggung jawab sosial dan manajemen laba.

\section{DAFTAR PUSTAKA}

Almalita, Y. (2018). Pengaruh Corporate Governance Dan Faktor Lainnya Terhadap Manajemen Laba. Jurnal Bisnis Dan Akuntansi, 19(2), 183-194. https://doi.org/10.34208/jba.v19i2.271

Amalia, B. Y., \& Didik, M. (2017). Pengaruh Konsentrasi Kepemilikan, Kepemilikan Institusional, Proporsi Dewan Komisaris Indenepden, dan Frekuensi Rapat Komite Audit terhadap Praktik Manajemen Laba. 6, 1-14.

Anwar, H., \& Buvanendra, S. (2016). Earnings Management and Ownership Structure: Evidence from Sri Lanka. Colombo Business Journal. 
https://doi.org/10.4038/cbj.v10i1.42

Ardiani, N. L. N., \& Sudana, I. P. (2018). Pengaruh Corporate Social Responsibility Pada Manajemen Laba. E-Jurnal Akuntansi, 24, 2333.

https://doi.org/10.24843/eja.2018.v24.i03.p26

Buertey, S., Sun, E., Lee, J. S., \& Hwang, J. (2019). Corporate social responsibility and earnings management: The moderating effect of corporate governance mechanisms. Corporate Social Responsibility and Environmental Management, 27.

Choi, B. B., Lee, D., \& Park, Y. (2013). Corporate social responsibility, corporate governance and earnings quality: Evidence from Korea. Corporate Governance: An International Review, 21(5), 447-467. https://doi.org/10.1111/corg.12033

Dwiarti, R., \& Hasibuan, A. N. (2018). Pengaruh Profitabilitas, Risiko Keuangan dan Pertumbuhan Perusahaan terhadap Manajemen Laba pada Perusahaan Kosmetik dan Keperluan Rumah Tangga. Jurnal Manajemen Dan Keuangan, 8(1), 21-33. https://ejurnalunsam.id/index.php/jmk/article/view/1129

Febria, D. (2020). Pengaruh Leverage, Profitabilitas Dan Kepemilikan Manajerial Terhadap Manajemen Laba. SEIKO : Journal of Management \& Business, 3(2), 65. https://doi.org/10.37531/sejaman.v3i2.568

Habbash, M., \& Haddad, L. (2019). The impact of corporate social responsibility on earnings management practices: evidence from Saudi Arabia. Social Responsibility Journal, Vol. Ahead-of-Print No. Ahead-of-Print.

Hastuti, C. S. F. (2019). Pengaruh Arus Kas Bebas, Arus Kas Operasi, Kepemilikan Manajerial, Leverage Keuangan Dan Ukuran Perusahaan Terhadap Manajemen Laba Pada Perusahaan Manufaktur Yang Terdaftar Di Bursa Efek Indonesia. Jurnal AKBIS Media Riset Akuntansi Dan Bisnis, 3(1), 11-26.

Honarvar, M. H., \& Nakashima, M. (2014). A new measure for upright stability. Journal of Biomechanics, 47(2), 560-567. https://doi.org/10.1016/j.jbiomech.2013.09.028

Hopkins, M. (2014). (PDF) What is CSR all about? 1(September 2014), 4,037. https://www.researchgate.net/publication/272832575_What_is_CSR_all_about

Jordaan, L. A., Klerk, M. de, \& Villiers, C. J. de. (2018a). Corporate social responsibility and earnings management of South African companies. South African Journal of Economic and Management Sciences, 21(1), 1-13. https://doi.org/10.4102/sajems.v21i1.1849

Jordaan, L. A., Klerk, M. de, \& Villiers, C. J. de. (2018b). Corporate social responsibility and earnings management of South African companies. South African Journal of Economic and Management Sciences, 21(1). https://doi.org/10.4102/sajems.v21i1.1849

Kao, M.-F., Hodgkinson, L., \& Jaafar, A. (2019). Ownership structure, board of directors and firm performance: evidence from Taiwan. Corporate Governance (Bingley), 19(1), 189-216. https://doi.org/10.1108/CG-04-2018-0144

Khosheghbal, M., Amiri, A., \& Homayoon, A. (2015). Role of Audit Committees and Board of Directors in Reducing Earning Management of Companies Listed in Tehran Stock Exchange. International Journal of Economics and Financial Issues, O(0), 0. http:www.econjournals.com

Kumala, R., \& Siregar, S. V. (2020). Corporate social responsibility, family ownership and earnings management: the case of Indonesia. Social Responsibility Journal. https://doi.org/10.1108/SRJ-09-2016-0156 
Kusmayadi, D., \& Badruzaman, J. (2018). Good corporate governance -. Wahana Islamika: Jurnal Studi Keislaman, 4(1), 127-149.

Latif dan Sajjad. (2020). CSR and EM. Csr and EM. https://doi.org/10.1002/csr.1803

Latif, K. F., \& Sajjad, A. (2018). Measuring corporate social responsibility: A critical review of survey instruments. Corporate Social Responsibility and Environmental Management, 25(6), 1174-1197. https://doi.org/10.1002/csr.1630

López-González, E., Martínez-Ferrero, J., \& García-Meca, E. (2019). Does corporate social responsibility affect earnings management? Evidence from family firms. REVISTA DE CONTABILIDAD SPANISH ACCOUNTING REVIEW 22 (2).

Medyawati, H., \& Dayanti, A. (2016). Pengaruh Ukuran Perusahaan Terhadap Manajemen Laba: Analisis Data Panel. Jurnal Ilmiah Ekonomi Bisnis, 21(3), 96409. https://doi.org/10.35760/eb.

Nariastiti, N. W., \& Ratnadi, N. M. D. (2014). Pengaruh Asimetri Informasi, Corporate Governance Dan Ukuran Perusahaan Pada Manajemen Laba. E-Jurnal Akuntansi, 9(3), 717-727.

Ntim, C. G., \& Soobaroyen, T. (2013). Corporate governance and performance in socially responsible corporations: New empirical insights from a neo-institutional framework. Corporate Governance: An International Review, 21(5), 468-494. https://doi.org/10.1111/corg.12026

Pekovic, S., \& Vogt, S. (2020). The fit between corporate social responsibility and corporate governance: the impact on a firm's financial performance. In Review of Managerial Science (Issue 0123456789). Springer Berlin Heidelberg. https://doi.org/10.1007/s11846-020-00389-x

Pieritsz, L. R. (2021). Peran Tata Kelola Perusahaan dan Tanggung Jawab Sosial Perusahaan Terhadap Manajemen Laba. Accounting and Business Information Systems Journal, 9(2).

Putriana, M., Artati, S., \& Utami, V. J. (2018). Pengaruh Corporate Social Responsibility Terhadap Manajemen Laba Dengan Leverage Dan Growth Sebagai Variabel Control Pada Industri Farmasi Yang Terdaftar Di Bursa Efek Indonesia. J-MAS (Jurnal Manajemen Dan Sains), 3(2), 226. https://doi.org/10.33087/jmas.v3i2.60

Sembiring, C. L. (2017). Manajemen Laba dan Pengungkapan Tanggung Jawab Sosial Perusahaan dengan Komisaris Independen dan Kepemilikan Institusional sebagai Variabel Pemoderasi. Berkala Akuntansi Dan Keuangan Indonesia, 2(1), $20-41$. https://doi.org/10.20473/baki.v2i1.3544

Setiawan, D., Prabowo, R., Arnita, V., \& Wibawa, A. (2019). Does corporate social responsibility affect earnings management? Evidence from the Indonesian banking industry. Business: Theory and Practice, 20(2010), 372-378. https://doi.org/10.3846/btp.2019.35

Sial, M. S., Chunmei, Z., \& Khuong, N. V. (2019). Do female and independent directors explain the two-way relationship between corporate social responsibility and earnings management of Chinese listed firms? International Journal of Accounting and Information Management, 27(3), 442-460. https://doi.org/10.1108/IJAIM-032018-0027

Zaid, M. A. A., Abuhijleh, S. T. F., \& Pucheta-Martínez, M. C. (2020). Ownership structure, stakeholder engagement, and corporate social responsibility policies: The moderating effect of board independence. Corporate Social Responsibility and Environmental Management, 27(3), 1344-1360. https://doi.org/10.1002/csr.1888 